\title{
Keberlanjutan Rantai Nilai Komoditas Beras
}

Fitriania ${ }^{\mathrm{a}}$, Cholid Fatih ${ }^{\mathrm{b}}$, Sutarnic, Fembriarti Erry Prasmatiwi ${ }^{\mathrm{d}}$

aPoliteknik Negeri Lampung, Bandar Lampung, Indonesia. Email: fitriani@polinela.ac.id

${ }^{b}$ Politeknik Negeri Lampung, Bandar Lampung. Indonesia. Email: cholidfatih@polinela.ac.id

cPoliteknik Negeri Lampung, Bandar Lampung. Indonesia.Email: sutarni@polinela.ac.id

dUniversitas Lampung, Bandar Lampung. Indonesia. Email: feprasmatiwi@yahoo.com

\section{Article Info}

\section{Article history:}

Received 21 Desember 2020

Received in revised form 7 Januari 2021

Accepted 14 Januari 2021

DOI:

https://doi.org/10.32938/ag.v6i1.1240 Keywords:

Agroindustry

Rice

Agri-food

Value Chain

SMEs

\begin{abstract}
Abstrak
Understanding the linkage of a product flows along the commodity chain is important as the starting point in determining a sustainability strategy. The scope of the rice commodity value chain in this study involves farmers' rice production, small-scale rice mills and the home industry of rice milling. The study aims to identify commodity chains of rice in Lampung Province. The primary data from the rice processing industry and rice trading using a questionnaire guidance. The purposive sampling method is used by considering the rice milling business's representation related to the commodity chain. Qualitative analysis of the pattern of relations between business actors carried out with the agri-food value chain approach. The pattern of chain starts from the process of transforming raw materials into the manufactured and the final product until it reaches the end consumers. The commodity chain involved the flow of production, information (price and marketing chain), and income flow. Generally, there are 3-5 rice flour milling units in the village, with a $50-120 \mathrm{~kg} /$ month production volume. The average price of rice flour is Rp. 12,500/ kg. The ability to supply paddy grain for milling is $2-5$ tons/agent/week. Rice mills generally have 2-6 suppliers of fixed paddy grain. Information on product flow diagrams includes product types, ease of obtaining goods, time dependence, and ease of selling goods. Information on paddy grain prices on the supplier line is an average of $R p 4,500 / \mathrm{kg}$. The price of rice in the distribution line to the wholesale rice trader is $R p .8,500$. Meanwhile, the income stream provides information on the value of rice production revenue of 59.7 tons per month attaint to $R p 40.3$ million with a profit amount of $R p 318 / \mathrm{kg}$.
\end{abstract}

\section{Pendahuluan}

Padi dan perberasan merupakan pangan pokok strategis nasional. Pada sektor hulu, usahatani padi menghadapi persoalan keterbatasan lahan yang secara masif terkonversi untuk komoditas lain dan penggunaan di luar usahatani. Konversi lahan sawah di Jawa berkontribusi terhadap penurunan produksi pangan hingga setara 1,7 juta ton beras per tahunnya (Irawan $\&$ Friyatno, 2002). Upaya peningkatan kapasitas produksi padi selain menghadapi persoalan alih fungsi juga penurunan produktivitas dan ancaman perubahan iklim. Lebih lanjut juga menyebabkan penurunan kontribusi subsektor tanaman pangan terhadap output regional (Fitriani, 2017; Fitriani et al., 2011; Fitriani et al. 2014; Siregar et al. 2020).

Ketersediaan produksi padi menentukan pencapaian ketahanan pangan nasional. Kebutuhan pangan merupakan fungsi permintaan komoditas. Permintaan beras ditentukan oleh jumlah penduduk, pendapatan per kapita penduduk, harga beras, harga produk subtitusi (jagung dan ubi kayu), dan permintaan tahun lalu (Fauzan, 2020; Wahyunindyawati et al., 1998). Rantai nilai komoditas padi dan beras melibatkan banyak pelaku ekonomi, mulai dari petani produsen, pedagang pengumpul, penggilingan padi, pedagang beras besar, pedagang perantara, pengecer, hingga konsumen akhir.

Menurut catatan INDEF, jumlah penggilingan padi tidak sebanding dengan produksi gabah. Jumlah penggilingan padi mencapai 182.191 , dimana $8 \%$ diantaranya merupakan penggilingan padi besar dan 92\% merupakan penggilingan padi kecil dan penggilingan padi kecil keliling. Sementara penggilingan padi besar menguasai lebih dari $60 \%$ pasokan beras nasional. Akibatnya, penggilingan padi kecil kalah bersaing dengan penggilingan padi besar untuk mendapatkan gabah. Selain itu, penggilingan padi skala kecil sulit memperoleh akses ke perbankan untuk perbaikan mesin penggilingan, sehingga sulit bagi penggilingan padi kecil dapat lebih efisien. Pada pertengahan Agustus 2019, Perpadi mencatat bahwa 70\% penggilingan padi yang berskala kecil terpaksa berhenti beroperasi. Sementara itu, penggilingan padi besar juga menghadapi persoalan kapasitas belum terpakai (idle capacity) sebesar 64\% (Persatuan Penggilingan Padi dan Pengusaha Beras Indonesia (Perpadi) (dikutip dari Harian Bisnis.com, edisi 29 Agustus 2019).

Penggilingan padi pada daerah sentra produksi menjadi mata rantai pasok perdagangan utama ke Bandar Lampung, dan kabupaten lainnya. Pada tahun 2012 terdapat 7.426 penggilingan padi, terdiri dari 7.079 penggilingan padi tetap dan 347 penggilingan padi keliling. Kabupaten Lampung Tengah sebagai sentra produksi padi utama di Propinsi Lampung $(>22 \%)$ memiliki penggilingan padi tetap paling banyak. Keberadaan penggilingan padi keliling turut berkontribusi besar dalam menjawab kebutuhan akses pengolahan petani. 
Agroindustri beras lainnya yang berkembang adalah industri olahan aneka makanan berbahan baku beras. Di Propinsi Lampung agroindustri olahan beras ini umumnya berskala kecil dan menengah. Agroindustri beras skala kecil (UKM) dalam menjaga kontinuitas usahanya penting sekali memahami seluruh rangkaian arus produk sepanjang rantai nilai komoditas. Perspektif baru dalam penguatan kelembagaan agroindustri skala rakyat merupakan salah satu kunci yang dapat meningkatkan nilai komoditas produk pertanian primer. Agroindustri beras skala rakyat yang kokoh dan unggul akan menjadi mata rantai yang tangguh dalam sistem agri-food chain agribisnis. Keberhasilan pengembangan agroindustri beras penting dalam menjaga upaya stabilitas ketahanan pangan, terutama dalam menjaga sinergi hubungan dengan lini petani produsen. Jangan sampai petani produsen menghadapi kondisi menerima harga beli padi yang rendah dan merugikan.

Perubahan yang dapat diadopsi untuk memperbaiki kinerja rantai nilai agroindustri beras, profitabilitas, efisiensi, kerjasama, dan pemasaran perlu dipahami oleh segenap stakeholder yang terlibat di bisnis perberasan. Penerapan pada tingkat praktis agri-food chain agroindustri beras menjadi alat diagnostik untuk keberlanjutan bisnis, karena analisis rantai nilai memperhatikan kekhasan komoditas (Howieson et al. 2016; Mustapha, 2016).

Analisis agri-food value chain agroindustry beras diperlukan dalam membangun model keunggulan industri perberasan skala rakyat dan menjaga kelangsungan usaha dalam menghadapi persaingan industri yang semakin ketat. Maping pelaku (stakeholders beras) di Propinsi Lampung akan menjadi informasi kunci dalam mata rantai ketersediaan stok beras untuk menjaga kestabilan pasokan bagi kebutuhan konsumsi beras, sehingga dapat meminimalkan impor. Efisiensi pada setiap lini aliran aktivitas akan membuat agroindusri beras skala rakyat semakin unggul, produktif, dan berdaya saing. Lebih lanjut akan menjadi penggerak roda perekonomian yang memberikan kesejahteraan bagi masyarakat pertanian di perdesaan. Penelitian ini bertujuan untuk mengidentifikasi rantai komoditas pada agroindustri beras skala kecil di Propinsi Lampung.

\section{Metode}

Lokasi penelitian adalah sentra produksi padi dan agroindustri beras di Propinsi Lampung, meliputi: Kabupaten Lampung Tengah, Lampung Selatan, dan Pringsewu yang memiliki agroindustri beras paling dominan. Penentuan pelaku agroindustri beras dilakukan dengan metode stratifikasi berdasarkan nilai asset dan tenaga kerja sesuai dengan kriteria BPS (industri skala mikro/kecil dan menengah). Masing-masing strata diwakili oleh 2 pelaku. Survei lapang berlangsung pada bulan Mei s.d. Juli 2018.

Data yang diperlukan dalam penelitian ini adalah data primer dari pelaku perdagangan beras dan data sekunder dari instansi terkait. Penelusuran keterkaitan dan pola hubungan antar aktor dalam setiap aktivitas mata rantai dilakukan secara deskriptif kualitatif. Bagan penelusuran sistem agri-food value chain agroindustri beras dapat dilihat pada gambar di bawah ini (Fagioli et al. 2017; Mustapha, 2016).

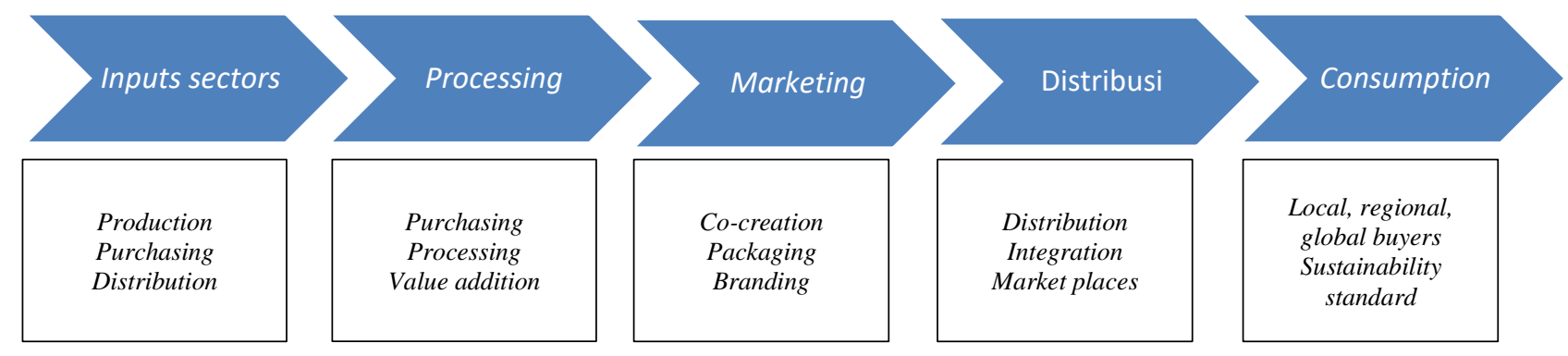

Gambar 1. Bagan sistem agri-food value chain agroindustri beras

\section{Hasil dan Pembahasan}

Aktivitas rantai nilai agribisnis pangan menciptakan alur nilai tambah, informasi, biaya, margin, dan dukungan kelembagaan dari produksi (petani), distribusi, pengolahan, dan pemasaran produk pertanian kepada konsumen akhir. Petani sebagai pelaku alur pertama rantai nilai melakukan fungsi pemasaran meliputi fungsi fisik (pengolahan, penyimpanan serta pengangkutan) dan fungsi pertukaran terdiri dari satu fungsi yaitu fungsi penjualan (De Araujo \& Nubatonis, 2016). Agri-food merupakan produk pangan yang diperoleh dari hasil pertanian. Istilah agri-food value chain (AVC) dikenal luas sebagai rantai nilai agribisnis pangan. Apa yang membedakan AVC dari rantai pasokan lain adalah karakteristik kualitas dan keamanan, termasuk 
umur simpan, variabilitas permintaan dan harga, yang membuat rantai pasokan menghadapi kondisi yang kompleks dan sulit dikelola daripada rantai pasokan lainnya (Ahumada \& Villalobos, 2009; Lim-Camacho et al. 2016). Aktivitas kerja yang saling terkait dan dilakukan oleh berbagai pihak (pemasok, produsen, dan bahkan pelanggan) dikenal sebagai rantai nilai. Rantai nilai berorientasi pada efektivitas dan menciptakan nilai tertinggi bagi pelanggan. Upaya mengubah berbagai sumber daya untuk menjadi sesuatu yang bernilai untuk pelanggan dan pelanggan bersedia membayarnya adalah rangkaian aktivitas panjang yang tidak sederhana dan mudah.

Berdasarkan hasil survei, responden adalah pedagang pengumpul atau disebut juga sebagai agen pemasok (intermediary supplier) sebanyak 25 pelaku, penggilingan padi (sebanyak 25 industri), pedagang perantara (intermediary trader) yang terdiri dari pedagang besar, sedang dan pengecer (retailer) sebanyak 25 pelaku. Konsumen akhir diwakili oleh 32 orang responden.

Pelaku agroindustri beras disajikan pada Tabel 1. Pelaku agroindustri beras diwakili oleh pelaku penggilingan padi (sebanyak 24 unit atau 75\%) dan penggilingan tepung beras sebanyak 8 unit $(25 \%)$.

Tabel 1. Pelaku agroindustri beras berdasarkan olahannya

\begin{tabular}{ccc}
\hline Bentuk produk & Pelaku & $(\%)$ \\
Beras & 24 & 75 \\
Tepung beras & 8 & 25 \\
\hline Jumlah & 32 & 100 \\
\hline
\end{tabular}

Pelaku usaha penggilingan beras menjadi tepung beras dilakukan oleh pelaku usaha skala rumahtangga. Keberadaan penggilingan tepung beras pada setiap desa berkisar 3-5 unit. Penggilingan tepung beroperasi setiap hari dengan volume giling $10-25 \mathrm{~g} / \mathrm{hari}$. Tepung beras hasil penggilingan beras biasa digunakan oleh pelaku usaha olahan pangan lokal. Produk tepung beras yang siap dikonsumsi oleh konsumen akhir umumnya produk pabrikan yang tersedia di toko/warung dengan volume pembelian $1-3 \mathrm{~kg} / \mathrm{minggu}$.

Kondisi volume transaksi usaha penggilingan padi secara deskriptif disajikan pada Tabel 2. Keuntungan usaha penggilingan padi berada pada kisaran Rp 47-63 juta per bulan. Maksimum volume transaksi pembelian bahan baku 20.000 ton per bulan.

Tabel 2. Kondisi transaksi penggilingan padi

\begin{tabular}{lrr}
\hline Transaksi & Minimum & Maximum \\
\hline Volume Beli (kg) & 2 & 20.000 \\
Lama Mitra (tahun) & 1 & 20 \\
Volume Jual (kg) & 2 & 20.000 \\
Harga Beli (Rp/kg) & 4.500 & 10.000 \\
Penerimaan (Rp) & 425.000 & 6.750 .000 .000 \\
Keuntungan (Rp) & 47.000 .000 & 63.997 .500 \\
\hline
\end{tabular}

Karakteristik demografi pelaku perdagangan meliputi umur, pengalaman dan Pendidikan dapat dilihat pada Tabel 3 berikut. Sebagian besar pelaku perdagangan (60\%) berusia antara $24-$ 45 tahun, dengan pengalaman berdagang antara 6-10 tahun. Pelaku perdagangan juga memiliki tingkat Pendidikan relatif baik, 62\% Pendidikan menengah hingga perguruan tinggi.

Tabel 3. Karakteristik pedagang (intermediary supplier/trader) beras

\begin{tabular}{lcc}
\hline Umur (tahun) & Responden & $(\%)$ \\
\hline $24-25$ & 8 & 32 \\
$36-45$ & 7 & 28 \\
$46-55$ & 7 & 28 \\
$>56$ & 3 & 12 \\
Pengalaman (tahun) & & 28 \\
$1-5$ & 7 & 36 \\
6-10 & 9 & 36 \\
Pendidikan & & 28 \\
SD & 9 & 16 \\
LSP & 7 & 4 \\
SLTA & 4 & 16 \\
SMK & 1 & 4 \\
Perguruan Tinggi & 4 & \\
\end{tabular}


Tabel 4. Komponen biaya pedagang (intermediary supplier/trader) beras

\begin{tabular}{lcrrr}
\hline Komponen biaya & Resp & Min & Max & Mean \\
\hline Nilai Bangunan (Rp) & 15 & 5.000 .000 & 50.000 .000 & $16.448 .000,00$ \\
Nilai Timbangan (Rp) & 23 & 50.000 & 6.000 .000 & $876.086,96$ \\
Nilai Kendaraan (Rp) & 16 & 12.000 & 409.000 .000 & $53.822 .625,00$ \\
Nilai alat lain (Rp) & 18 & 3.333 & 2.500 .000 & $171.351,83$ \\
Biaya Penyusutan (Rp) & 16 & 1.700 & 10.000 .000 & $3.664 .994,25$ \\
Biaya bahan bakar (Rp) & 15 & 3.725 & 160.000 & $35.341,67$ \\
Biaya TK (Rp) & 15 & 20.000 & 300.000 & $65.491,07$ \\
Biaya kemasan (Rp) & 14 & 1.400 & 140.000 & $22.200,00$ \\
Biaya tali (Rp) & 7 & 272 & 350.000 & $59.896,00$ \\
Biaya Retribusi (Rp) & 1 & 15.000 & 15.000 & $15.000,00$ \\
Sewa bulanan (Rp) & 13 & 8.000 & 18.000 .000 & $3.607 .829,00$ \\
Biaya listrik (Rp/bl) & 15 & 833 & 2.160 .000 & $336.255,53$ \\
Biaya operasi (Rp/hr) & 22 & 4.000 & 19.441 .400 & $2.088 .519,68$ \\
\hline
\end{tabular}

Komponen biaya yang dikeluarkan oleh pedagang beras besar dan perantara dapat dilihat pada tabel berikut ini. Rataan biaya operasional per bulan mencapai Rp 2,088 juta dapat dilihat pada tabel 4.

Sementara itu, volume perdagangan intermediary trader dalam satu bulan dapat dilihat sebagaimana Tabel 5 berikut ini.

Tabel 5. Volume bisnis pedagang ( intermediary trader) beras

\begin{tabular}{lcrrr}
\hline Komponen & Resp & Min & Max & Mean \\
\hline Volume pembelian1 $1 \mathrm{~kg})$ & 21 & 22 & 8.000 & 883,81 \\
Harga Beli1 (Rp/kg) & 22 & 2.000 & 10.000 & $8.322,73$ \\
Volume penjualan1 $(\mathrm{kg})$ & 21 & 10 & 8.000 & 592,38 \\
Harga Jual1 $(\mathrm{Rp} / \mathrm{kg})$ & 23 & 2.500 & 15.000 & $9.134,78$ \\
Volume beli2 $(\mathrm{kg})$ & 9 & 15 & 10.000 & $1.367,00$ \\
Harga beli2 $(\mathrm{Rp} / \mathrm{kg})$ & 9 & 8.000 & 11.500 & $9.366,67$ \\
Volume jual2 $(\mathrm{kg})$ & 10 & 10 & 1.000 & 204,50 \\
Harga jual2 $(\mathrm{Rp} / \mathrm{kg})$ & 10 & 1.500 & 12.000 & $9.090,00$ \\
Volume beli3 $(\mathrm{kg})$ & 4 & 150 & 1.000 & 787,50 \\
Harga beli3 $(\mathrm{Rp} / \mathrm{kg})$ & 3 & $7.7 .$. & 8.600 & $8.300,00$ \\
Volume jual3 $(\mathrm{kg})$ & 4 & 150 & 400 & 287,50 \\
Harga jual3 $(\mathrm{Rp} / \mathrm{kg})$ & 4 & 8.500 & 10.000 & $9.075,00$ \\
\hline
\end{tabular}

Pergerakan harga produk dari lini produsen berupa gabah di tingkat petani hingga konsumen akhir disajikan pada Tabel 6 berikut ini.

Tabel 6. Alir informasi harga rantai nilai agroindustri beras skala kecil

\begin{tabular}{cccccc}
\hline Petani & Agen I & Agen II & Penggilingan beras & Grosir beras & Retail beras \\
\hline 4.000 & 4.300 & 4.400 & 4.500 & 8.500 & 12.300 \\
\hline
\end{tabular}

Pengembangan konsep rantai nilai bisnis banyak digunakan sebagai strategi bisnis untuk memenangkan persaingan dan mempertahankan keunggulan bisnis. Pada tataran aplikasi hal ini dapat menimbulkan potensi eksploitasi dan merugikan bagi pihak yang memiliki daya tawar lemah dan akses terbatas terhadap pasar dan modal. Penerapan konsep rantai nilai penting diarahkan untuk memperkuat secara simultan setiap pihak yang terlibat dalam rantai bisnis. Bukan hanya bagi yang memiliki kapital tetapi merupakan bagian penting dalam memperkuat rantai pasokan untuk mempertahankan dan memperluas jejaring bisnis secara lebih berkelanjutan. Proses inti rantai nilai agroindustri merupakan kesatuan aktivitas alir mulai dari penggunaan input atau sarana produksi sebagai bahan baku hingga konsumsi akhir produk akhir. Aktivitas yang masuk pada proses inti tergantung pada karakteristik rantai komoditas yang dipetakan. Proses inti rantai nilai agroindustri beras skala kecil dan pemetaan para pelaku utama yang terlibat dalam rantai nilai dilakukan dengan cara menelusuri pihak-pihak yang terlibat dalam proses inti tersebut. Selanjutnya gambaran pemetaan aktivitas pelaku utama dalam rantai nilai agroindustry beras disajikan pada Gambar 2.

Pada Gambar 2 dapat dilihat bahwa aliran bahan baku berupa gabah hasil produksi padi petani menjadi input bagi pelaku agroindustri dapat secara langsung atau melalui intermediary supplier atau agen (pedagang pengumpul) perantara ke penggilingan padi. Selanjutnya dari 
penggilingan padi proses transformasi gabah menjadi beras sesuai dengan standar mutu yang ditentukan dilakukan. Produksi beras yang telah dikemas siap untuk didistribusikan ke pedagang besar grosir maupun perantara hingga ke pedagang pengecer dan kepada konsumen akhir.

Pelaku utama yang terlibat pada lini pasokan adalah petani padi dan pedagang pengumpul atau agen pedagang mitra pabrikan beras. Keberadaan agen pedagang sebagai intermediary supplier penting bagi pabrikan beras dalam memastikan pasokan gabah dari petani sebagai bahan baku. Pasokan utama bahan baku gabah baik dalam kondisi kering giling maupun kering panen dilakukan oleh intermediary trader ini. Petani yang langsung melakukan pengiriman gabah ke penggilingan padi hanya sedikit, umumnya digunakan untuk beras konsumsi dalam jumlah yang terbatas. Setiap pabrikan penggilingan padi memiliki mitra intermediary trader ini pada kisaran 35 orang pemasok. Baik penggilingan padi tetap, keliling maupun penggilingan tepung beras minimal terdapat satu unit dalam setiap desa sampling. Aktivitas penggilingan padi dalam mengelola rantai pasokan mengerahkan tenaga pembelian gabah (pedagang pengumpul kecil) pada saat panen. Berdasarkan penelitian (Zakaria, 2007) satu orang pedagang bisa mendapat modal setara 20 ton gabah kering panen. Penggilingan melakukan pembelian cadangan gabah pada periode Maret - Juni dan periode Desember - Januari dalam setahun, sehingga cadangan gabah yang diperoleh antara 75 - 120 ton gabah kering panen per tahun.

Sementara itu pelaku pedagang beras desa umumnya sekitar 3-5 orang dan pedagang beras retail (eceran) mencapai 10-15 pedagang. Berdasarkan kegiatan spesifik yang dijalankan oleh pelaku pada tiap rantai nilai memiliki proses utama dan kegiatan spesifik masing-masing. Rincian secara spesifik berdasarkan aktivitas setiap pelaku rantai nilai dapat dilihat pada Gambar 3.

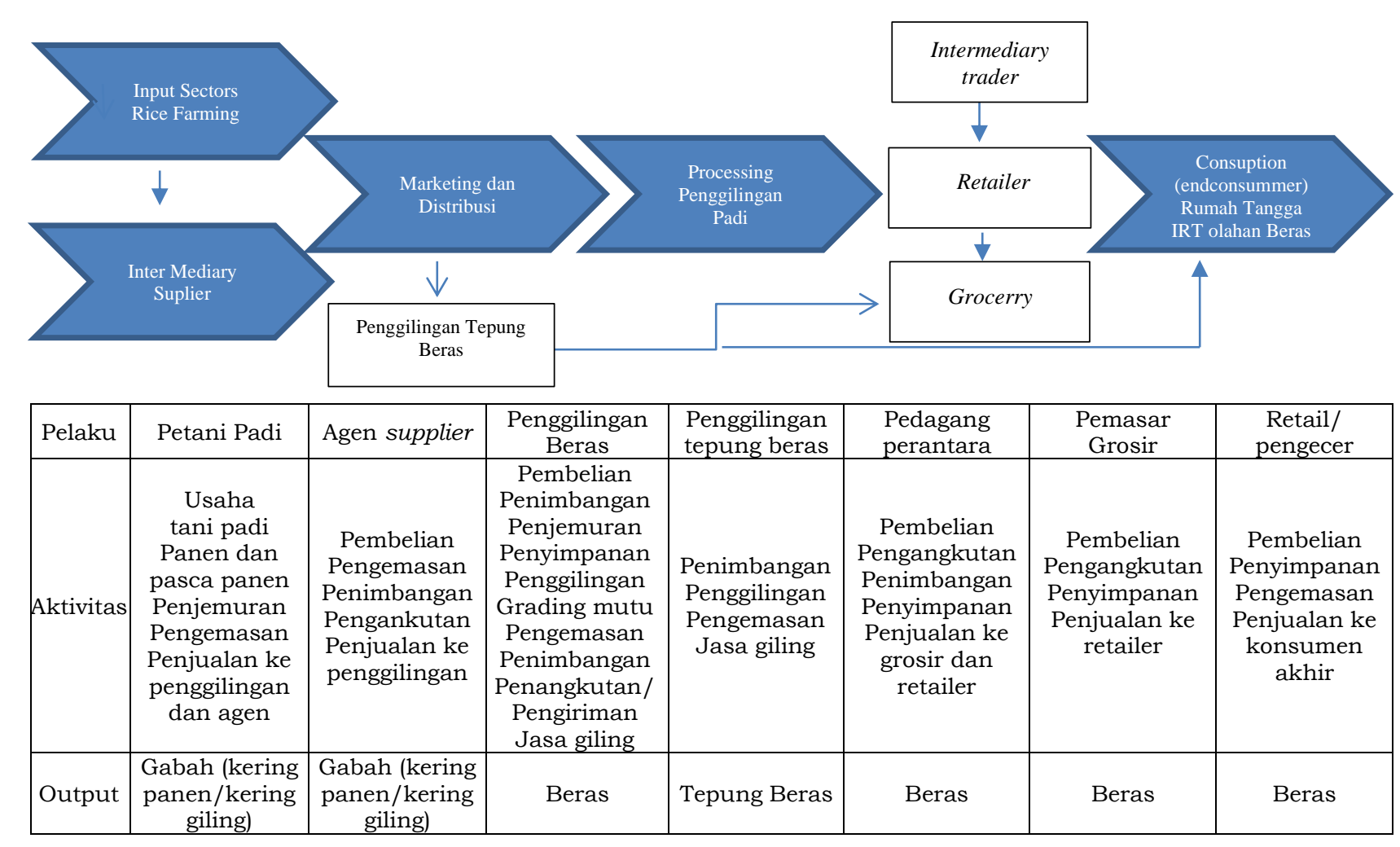

Gambar 2. Proses inti dan aktivitas pelaku dalam rantai nilai agroindustri beras

Pelaku utama yang terlibat pada lini pasokan adalah petani padi dan pedagang pengumpul atau agen pedagang mitra pabrikan beras. Keberadaan agen pedagang sebagai intermediary supplier penting bagi pabrikan beras dalam memastikan pasokan gabah dari petani sebagai bahan baku. Pasokan utama bahan baku gabah baik dalam kondisi kering giling maupun kering panen dilakukan oleh intermediary trader ini. Petani yang langsung melakukan pengiriman gabah ke penggilingan padi hanya sedikit, umumnya digunakan untuk beras konsumsi dalam jumlah yang terbatas. Setiap pabrikan penggilingan padi memiliki mitra intermediary trader ini pada kisaran 35 orang pemasok. Baik penggilingan padi tetap, keliling maupun penggilingan tepung beras minimal terdapat satu unit dalam setiap desa sampling. Aktivitas penggilingan padi dalam mengelola rantai pasokan mengerahkan tenaga pembelian gabah (pedagang pengumpul kecil) pada saat panen. Berdasarkan penelitian (Zakaria, 2007) satu orang pedagang bisa mendapat modal 
setara 20 ton gabah kering panen. Penggilingan melakukan pembelian cadangan gabah pada periode Maret - Juni dan periode Desember - Januari dalam setahun, sehingga cadangan gabah yang diperoleh antara $75-120$ ton gabah kering panen per tahun.

\begin{tabular}{|c|c|c|c|c|c|c|c|c|}
\hline Proses & $\begin{array}{l}\text { Usahatani } \\
\text { Padi }\end{array}$ & $\begin{array}{c}\text { Pengadaan } \\
\text { Gabah }\end{array}$ & $\begin{array}{c}\text { Penggilingan } \\
\text { Beras }\end{array}$ & $\begin{array}{l}\text { Penggilingan } \\
\text { tepung beras }\end{array}$ & $\begin{array}{l}\text { Pedagang } \\
\text { perantara }\end{array}$ & $\begin{array}{l}\text { Pemasar } \\
\text { Grosir }\end{array}$ & $\begin{array}{l}\text { Retail/ } \\
\text { pengecer }\end{array}$ & $\begin{array}{c}\text { Pelaku } \\
\text { olahan } \\
\text { pangan } \\
\text { beras }\end{array}$ \\
\hline $\begin{array}{l}\text { Bentuk } \\
\text { input/ } \\
\text { Sarana } \\
\text { produksi }\end{array}$ & \begin{tabular}{|c|} 
Bibit \\
Pupuk \\
TK \\
Pengendali OPT \\
Peralatan \\
pertanian
\end{tabular} & $\begin{array}{c}\text { Gabah } \\
\text { Peralatan } \\
\text { timbang, Alat } \\
\text { kadar air } \\
\text { Karung } \\
\text { kemasan } \\
\text { Kendaraan } \\
\text { angkut }\end{array}$ & $\begin{array}{c}\text { Gabah } \\
\text { Peralatan } \\
\text { timbang, Alat } \\
\text { kadar air } \\
\text { Karung } \\
\text { kemasan } \\
\text { Kendaraan } \\
\text { angkut } \\
\text { Alat Grading } \\
\text { mutu } \\
\text { Kendaraan } \\
\text { angkutan } \\
\text { Gudang } \\
\end{array}$ & $\begin{array}{c}\text { Beras } \\
\text { Alat timbang } \\
\text { Penggilingan } \\
\text { Plastik } \\
\text { kemasan }\end{array}$ & $\begin{array}{c}\text { Beras } \\
\text { Alat } \\
\text { angkutan } \\
\text { Alat } \\
\text { timbangan } \\
\text { Gudang } \\
\text { Karung } \\
\text { kemas } \\
\text { berbagai } \\
\text { ukuran }\end{array}$ & $\begin{array}{c}\text { Beras } \\
\text { Alat } \\
\text { angkutan } \\
\text { Alat } \\
\text { timbangan } \\
\text { Gudang } \\
\text { Karung } \\
\text { kemas } \\
\text { berbagai } \\
\text { ukuran }\end{array}$ & $\begin{array}{c}\text { Beras } \\
\text { Alat } \\
\text { angkutan } \\
\text { Alat } \\
\text { timbangan } \\
\text { Gudang } \\
\text { Karung } \\
\text { kemas } \\
\text { berbagai } \\
\text { ukuran }\end{array}$ & \begin{tabular}{|c|} 
Beras \\
Tepung \\
Beras \\
Bahan dan \\
Peralatan \\
kue \\
Kemasan
\end{tabular} \\
\hline $\begin{array}{l}\text { aliran } \\
\text { Output }\end{array}$ & $\begin{array}{c}\text { Gabah (kering } \\
\text { panen/kering } \\
\text { giling) }\end{array}$ & $\begin{array}{l}\text { Gabah (kering } \\
\text { panen/kering } \\
\text { giling) }\end{array}$ & Beras & Tepung Beras & Beras & Beras & Beras & $\begin{array}{c}\text { Aneka } \\
\text { snack/ } \\
\text { kue dari } \\
\text { beras }\end{array}$ \\
\hline
\end{tabular}

Gambar 3. Alur produk agroindustri beras skala kecil

Sementara itu pelaku pedagang beras desa umumnya sekitar 3-5 orang dan pedagang beras retail (eceran) mencapai 10-15 pedagang. Berdasarkan kegiatan spesifik yang dijalankan oleh pelaku pada tiap rantai nilai memiliki proses utama dan kegiatan spesifik masing-masing. Rincian secara spesifik berdasarkan aktivitas setiap pelaku rantai nilai dapat dilihat pada Gambar 3.

Keterkaitan antara aktivitas dan pelaku yang terlibat dalam membawa produk atau layanan dari produksi hingga konsumsi dapat menciptakan nilai saling ketergantungan sehingga apa yang terjadi pada satu titik dalam rantai memiliki konsekuensi bagi para aktor dan aktivitas di titik lain dalam rantai. Pada kondisi situasi pasar yang sangat kompleks, keberhasilan satu perusahaan bergantung pada aktivitas perusahaan lain. Potensi komunikasi dan koordinasi rantai nilai akan bervariasi, terutama yang berkaitan dengan ukuran perusahaan. Perusahaan besar memiliki kapasitas untuk menciptakan keterkaitan nilai yang merespons kebutuhan mereka, menggunakan kekuatan pasar dan sumber daya mereka untuk memberikan sanksi positif dan negatif kepada mitra dalam rantai nilai aktual dan potensial. Perusahaan yang lebih kecil tidak memiliki kekuatan atau sumber daya untuk membentuk rantai nilai dengan cara ini. Oleh karenanya, hadirnya peraturan (formal dan informal) dalam membentuk pasar dalam memfasilitasi interaksi pasar menjadi sangat vital (Henson \& Humphrey, 2015). Pilihan perusahaan penting berlandaskan pada penilaian kemampuan penyediaan layanan ekosistem dan keberlanjutan jangka panjang sektor pertanian berorientasi ekspor (Rueda et al., 2017).

\section{Simpulan}

Rantai nilai komoditas pada agroindustri beras skala kecil di Propinsi Lampung melibatkan aktivitas olahan (processing) industri rumah tangga (IRT) penggilingan tepung beras dan penggilingan padi skala kecil, serta IRT olahan pangan. Pelaku yang terlibat dalam aliran produk meliputi petani padi, pedagang pengumpul/pemasok gabah, penggilingan padi, penggilingan tepung, pemasar/pedagang grosir, pedagang retail/pengecer, dan pelaku IRT olahan pangan berbasis tepung beras. Pelaku IRT penggilingan tepung beras yang ada di desa sebanyak 3-5 unit, dengan volume produksi $50-120 \mathrm{~kg} /$ bulan. Harga tepung beras rerata Rp 12.500/kg. Kemampuan pasokan gabah untuk penggilingan sebesar 2-5 ton/agen/minggu. Penggilingan beras umumnya memiliki 2-6 pemasok gabah tetap. Informasi harga gabah pada lini pemasok rata-rata sebesar Rp $4.500 / \mathrm{kg}$. Harga beras pada lini distribusi ke pedangang beras/grosir sebesar Rp 8.500. Sementara itu, aliran pendapatan memberikan informasi nilai penerimaan produksi beras 59,7 ton per bulan sebesar Rp 40,3 juta dengan keuntungan sebesar Rp 318/kg. UKM perberasan penting membangun jejaring rantai pasokan dan distribusi secara efisien agar dapat unggul, produktif, dan berdaya saing. Penguatan kelembagaan UKM pangan strategis diperlukan dalam memastikan kestabilan harga dan pasokan pangan untuk mencapai target ketahanan pangan nasional. 


\section{Pustaka}

Ahumada, O., \& Villalobos, J. R. (2009). Application of planning models in the agri-food supply chain: A review. European Journal of Operational Research, 196(1), 1-20. https://doi.org/10.1016/j.ejor.2008.02.014

De Araujo, M., \& Nubatonis, A. (2016). Analisis Produksi dan Pemasaran Usahatani Padi Sawah di Desa Tualene Kecamatan Biboki Utara Kabupaten Timor Tengah Utara. Agrimor, 1(03), 5556. https://doi.org/10.32938/ag.v1i03.262

Fagioli, F. F., Rocchi, L., Paolotti, L., Słowiński, R., \& Boggia, A. (2017). From the farm to the agrifood system: A multiple criteria framework to evaluate extended multi-functional value. Ecological Indicators, 79(April), 91-102. https://doi.org/10.1016/j.ecolind.2017.04.009

Fauzan, M. (2020). Efisiensi Ekonomi Usahatani Padi Lahan Kering di Kabupaten Lampung Selatan. Agrimor, 5(3), 45-47. https://doi.org/10.32938/ag.v5i3.1018

Fitriani. (2017). Climate Changing Impact on Rice Production. JoFSA, 1(1), 41-46.

Fitriani, Ismono, H., \& Rosanti, N. (2011). Produksi dan tataniaga beras di propinsi lampung. $J$ SEP, 5(1), 1-11.

Fitriani, Sutarni, Ismono, H., \& Haryono, D. (2014). Kinerja Sub Sektor Tanaman Pangan pada Sektor Pertanian Lampung. In J. H. M. S. Muslimin, T. A. D. Nugroho, G. W. F. Rohmah, L. F. L. P. H. Perwitasari, \& Diterbitkan (Eds.), Prosiding Seminar Nasional Kedaulatan Pangan dan Pertanian (pp. 212-220). Yogyakarta: Jurusan Sosial Ekonomi Pertanian Faperta UGM.

Henson, S., \& Humphrey, J. (2015). Review of Agri-Food Value Chain Interventions - Assessing the Effectiveness of Agri-Food Value Chain Interventions Aimed at Enhancing Consumption of Nutritious Food by the Poor: Conceptual Framework. LANSA Working Paper Series, 2015(04), $1-27$. Retrieved

from http://lansasouthasia.org/sites/default/files/LANSA_Pillar_2_2_Conceptual_Framework_fe b.pdf

Howieson, J., Lawley, M., \& Hastings, K. (2016). Value chain analysis: an iterative and relational approach for agri-food chains. Supply Chain Management: An International Journal, 21(3), 352-362. https://doi.org/10.1108/SCM-06-2015-0220

Irawan, B., \& Friyatno, S. (2002). Dampak Konversi Lahan Sawah Di Jawa Terhadap Produksi Beras Dan Kebijakan Pengendaliannya. SOCA, 2(2), 1-33.

Lim-Camacho, L., Crimp, S., Ridoutt, B., Ariyawardana, A., Bonney, L., Lewis, G., ... Nelson, R. (2016). Adaptive value chain approaches Understanding adaptation in food value chains. Australia.

Mustapha, Y. I. (2016). Value Chain Analysis and the Performance of Small Scale Agri-business: Evidence from Cultured Fish Farmers Kwara State. JOURNAL OF MARKETING DEVELOPMENT (JMD), 1(August 2017), 85-102.

Rueda, X., Garrett, R. D., \& Lambin, E. F. (2017). Corporate investments in supply chain sustainability: Selecting instruments in the agri-food industry. Journal of Cleaner Production, 142, 2480-2492. https://doi.org/10.1016/j.jclepro.2016.11.026

Siregar, A. P., Oktaviana, N., \& Tarsilohadi, E. R. (2020). The Development of Rice Field Area in Special Region of Yogyakarta. SOCA: Jurnal Sosial Ekonomi Pertanian, 14(3), 557-571. https://doi.org/https://doi.org/10.24843/SOCA.2020.v14.i03.p16

Wahyunindyawati, Fernandes, A. A. R., \& Andri, K. B. (1998). Model regresi time series untuk peramalan pertumbuhan permintaan beras. SOCA, 11(1).

Zakaria, W. A. (2007). Analisis Cadangan Beras Masyarakat di Provinsi Lampung. SOCA, 9(2), 178184. 